\title{
Magnitude and determinants of neural tube defect in Africa: a systematic review and meta-analysis
}

Daniel Atlaw ${ }^{1 *}$ D, Yohannes Tekalegn², Biniyam Sahiledengle², Kenbon Seyoum³, Damtew Solomon', Habtamu Gezahegn ${ }^{4}$, Zerihun Tariku ${ }^{5}$, Yared Tekle ${ }^{5}$ and Vijay Kumar Chattu ${ }^{6}$

\begin{abstract}
Background: Neural tube defects (NTDs) are a group of disorders that arise from the failure of the neural tube close between 21 and 28 days after conception. About 90\% of neural tube defects and 95\% of death due to these defects occurs in low-income countries. Since these NTDs cause considerable morbidity and mortality, this study aimed to determine the prevalence and associated factors of NTDs in Africa.

Methods: The protocol of this study was registered in the International Prospective Register of Systematic Reviews (PROSPERO number: CRD42020149356). All major databases such as PubMed/MEDLINE, EMBASE, CINAHL, Web of Science, African Journals Online (AJOL), and Google Scholar search engine were systematically searched. A randomeffect model was used to estimate the pooled prevalence of NTDs in Africa, and Cochran's Q-statistics and I ${ }^{2}$ tests were used to assess heterogeneity between included studies. Publication bias was assessed using Begg 's tests, and the association between determinant factors and NTDs was estimated using a random-effect model.

Results: Of the total 2679 articles, 37 articles fulfilled the inclusion criteria and were included in this systematic review and meta-analysis. The pooled prevalence of NTDs in Africa was 50.71 per 10,000 births (95\% Cl: 48.03, 53.44). Folic acid supplementation (AOR: 0.40; 95\% Cl: 0.19-0.85), maternal exposure to pesticide (AOR: 3.29; 95\% Cl: 1.04-10.39), mothers with a previous history of stillbirth (AOR: $3.35,95 \% \mathrm{Cl}: 1.99-5.65$ ) and maternal exposure to x-ray radiation (AOR 2.34; 95\% Cl: 1.27-4.31) were found to be determinants of NTDs.

Conclusions: The pooled prevalence of NTDs in Africa was found to be high. Maternal exposure to pesticides and $x$-ray radiation were significantly associated with NTDs. Folic acid supplementation before and within the first month of pregnancy was found to be a protective factor for NTDs.
\end{abstract}

Keywords: Anencephaly, Spina bifida, Neural tube defect, Systematic review, Africa

\footnotetext{
* Correspondence: danielatmwu@gmail.com

'Department of Human Anatomy, School of Medicine, Goba Referral Hospital, Madda Walabu University, Goba, Ethiopia

Full list of author information is available at the end of the article
}

C C The Author(s). 2021 Open Access This article is licensed under a Creative Commons Attribution 4.0 International License, which permits use, sharing, adaptation, distribution and reproduction in any medium or format, as long as you give appropriate credit to the original author(s) and the source, provide a link to the Creative Commons licence, and indicate if changes were made. The images or other third party material in this article are included in the article's Creative Commons licence, unless indicated otherwise in a credit line to the material. If material is not included in the article's Creative Commons licence and your intended use is not permitted by statutory regulation or exceeds the permitted use, you will need to obtain permission directly from the copyright holder. To view a copy of this licence, visit http://creativecommons.org/licenses/by/4.0/. The Creative Commons Public Domain Dedication waiver (http://creativecommons.org/publicdomain/zero/1.0/) applies to the data made available in this article, unless otherwise stated in a credit line to the data. 


\section{Background}

A neural tube defect (NTD) is a failure of the neural tube to close during the 3rd and 4th weeks of pregnancy [1]. The development and closure of the neural tube are typically completed within 28 days after conception before many women are aware that they are pregnant [2]. Neural tube defects can be identified through simple prenatal testing using ultrasound imaging or maternal serum alpha-fetoprotein level screening [3].

Neural tube defect is estimated to affect about 300,000 newborns worldwide in 2016 [4], resulting in about 88, 000 deaths per year [4]. In low-income countries, NTDs may account for $29 \%$ of neonatal deaths due to observable birth defects [4]. The burden of NTDs in developing countries have been reported to be two times higher than in developed countries [5]. In Africa, the median NTD prevalence was 11.7 per 10,000 births [4]. A review conducted in 2016 stated that nearly 270, 000 NTDs occur due to lack of folic acid fortification; this estimate, however, might be impacted due to the paucity of data [6].

From different forms of neural tube defects, anencephaly and spina bifida are prevalent in developing countries [7]. Anencephaly is invariably associated with death as a stillbirth, a neonatal death, and a post-neonatal death [8]. In many cases, NTDs will end up in different forms of complications like mortality, disabilities, and psychological disorders of affected families [8].

Neural tube defects do not have specific causative agents, but genetic, environmental, and maternal age factors were among common contributors [9]. Maternal hypertension and maternal fever during pregnancy were identified as risk factors for NTDs [10]. Maternal history of alcohol intake during pregnancy was found to be significantly associated with NTDs [11]. Consanguineous marriage is also listed as a common factor for NTDs [12].

Neural tube defects are among commonly avoidable defects; it is estimated that $50-60 \%$ of these defects could be prevented by achieving and maintaining adequate folate levels before and within the first month of pregnancy [13]. A global review conducted in 2014 tried subgroup analysis for Africa on the burden of neural tube defect. Still, they have included limited studies which may affect the overall magnitude of NTDs [3]. Even though some global reviews have been conducted to assess the burden of NTDs, none of them reported determinant factors $[3,4,6,8]$. Therefore, this systematic review and meta-analysis aimed to determine the pooled prevalence and determinants of NTDs in Africa. Determining the most avoidable risk factors will assist policymakers in designing strategies to decrease the burden of neural tube defects in Africa.

\section{Methods}

\section{Study protocol}

The protocol of this study was registered in the International Prospective Register of Systematic Reviews (PROSPERO), the University of York Centre for Reviews and Dissemination (ID number: CRD42020149356) [14]. This review and meta-analysis were conducted according to the guideline of Preferred Reporting Items for Systematic reviews and Meta-Analysis (PRISMA) (additional file 1) [15].

\section{Search strategy}

A systematic review and meta-analysis were conducted using published and unpublished articles on the prevalence and associated factors of NTDs in Africa. The databases used to search for studies were PubMed, EMBASE, Google Scholar, CINAHL, POPLINE, and African Journals Online (AJOL), and grey literature was searched on Google and Research Gate. The following vital terms neural AND tube AND defect AND "determinant factors" OR "associated factors" OR "protective factors" OR "risk factors" AND "Africa countries" were used separately or in combination with the Boolean operator's terms "AND" and "OR." The search was also done by combining the above search terms with the names of all countries included in Africa and the sub-region of Africa (additional file 2). The reference lists of the retrieved studies were also scanned to access additional articles and screened against our eligibility criteria.

\section{Eligibility criteria}

Any study in Africa that reported magnitude and determinant factors for NTDs and fulfilled the following criteria were recruited into the analysis:

\section{Study area}

All studies conducted in African countries.

\section{Population}

Epidemiological studies had reported prevalence and risk factors of NTDs as an outcome.

\section{Study designs}

All observational studies (cross-sectional, case-control, and cohort) reporting the prevalence and determinants of NTDs were eligible for this systematic review and meta-analysis.

\section{Language}

Articles published in English were considered.

\section{Publication status}

Both published and unpublished articles were considered. 


\section{Study period}

No restriction of the period applied to this review.

\section{Study selection}

Important articles identified from the databases mentioned above and websites were imported into an Endnote X8, and duplicates were removed. Screening retrieved articles titles, abstracts, and full-text quality was conducted independently by two review authors (DA \& KS) based on the eligibility criteria. The disagreement between the two reviewers was resolved by reaching a consensus through discussion.

\section{Risk of bias assessment}

The study risk of bias was assessed using the Joana bridge institute (JBI) critical appraisal tool [16]. Two authors (DA \& KS) evaluated the quality of the full text considered to be included in the meta-analysis. The tool consists of ten items for case-control and eight for cross-sectional studies (additional files 3 and 4). Each item for each study was judged as Yes (1) and No (0). When the information provided was not adequate to make a judgment for a specific item, we agreed to grade that item with a 'No' (0). Each study was graded depending on the number of items judged 'Yes' (1) as low risk $(\geq 7)$, medium risk (5 to 6 ) or high risk $(\leq 4)$ for crosssectional studies and low risk ( $\geq 8)$, medium risk (7 to 6 ) and high risk $(<5)$ for case-control studies (additional files 3 and 4).

\section{Data extraction}

The selected papers were thoroughly reviewed, and the required information for the systematic review was extracted and summarized using an extraction table in Microsoft Office Excel software (additional files 5 and 6).

The data extraction tool consists of the name of the author (s), country and sub-region, study design, setting, year of publication, sample size, and number of NTDs (additional file 5). Data were extracted in two-by-two tables for determinants of NTDs, pooled odds ratio with their corresponding 95\% confidence interval (CI) was calculated based on the original studies report (additional file 6).

\section{Statistical methods and analysis}

The extracted data were imported into STATA/SE version 14 software for all statistical analysis. The heterogeneity among all included studies was assessed by using the $\mathrm{I}^{2}$ statistics and Cochran $\mathrm{Q}$ test. In this meta-analysis, the tests indicate significant heterogeneity among included studies $\left(\mathrm{I}^{2}=100, P\right.$-value $\left.<.001\right)$. For this reason, we used a random-effects model as a method of analysis. The publication bias was assessed using begg 's test statistics. Pooled prevalence and odds ratios along their corresponding 95\% CI were presented using a forest plot. Subgroup analyses for the prevalence of NTDs were performed by sub-regions of Africa. To determine factors associated with NTDs, data were entered into Review Manager Version 5, and pooled odds ratios (ORs) with 95\% confidence interval (CI) were used.

\section{Operational definition}

Neural tube defects all newborns having one of the following defects are considered as having NTD. Spina bifida (meningocele and myelomeningocele), anencephaly, and encephalocele.

Prevalence of NTDs = number of a newborn with NTDs/total number of newborns *100

\section{Results}

The findings from this systematic review and metaanalysis are described in various sub-headings described below.

\section{Description of included studies}

A total of 2679 published articles were retrieved through the search strategies. Then, 2008 records were removed due to duplication. Furthermore, 598 records were excluded after screening by title and abstract. Finally, a total of 73 full-text articles were screened against the eligibility criterion, of which 37 articles meet the requirements to be included in the final analysis (Fig. 1).

\section{Characteristics of the included studies}

Fourteen African countries were represented in this review. Of these, 9 (24.3\%) of the studies were from West African [17-25], 18 (48.6\%) were from East African countries [26-43], 1(2.7\%) from Central Africa [44], 1 (2.7\%) from Southern Africa [45], and 8 (21.6\%) were from Northern African country [46-53]. Regarding the study design, twenty-nine (78\%) were cross-sectional, and eight $(22 \%)$ were case-control studies. Studies were categorized according to their quality; ten studies were considered to have high quality 10 (27\%), twenty-six medium quality $26(70 \%)$, and one study as having high low quality (Tables 1 and 2).

\section{Prevalence of neural tube defects (NTDs) in Africa}

Twenty-nine articles were included in the meta-analysis to estimate the prevalence of NTD in Africa. A total of $6,113,208$ newborns were included in the analysis. The included studies reported a sample size, ranging from the minimum of 84 participants in the Ethiopian study [27] to the maximum of $3,803,889$ in the Tunisian study [51]. The result of random-effect meta-analysis estimated the pooled prevalence of NTDs in Africa was 50.71 per 10,000 births (95\% CI: $48.03,53.44 ; \mathrm{I}^{2}=100 \%$, 


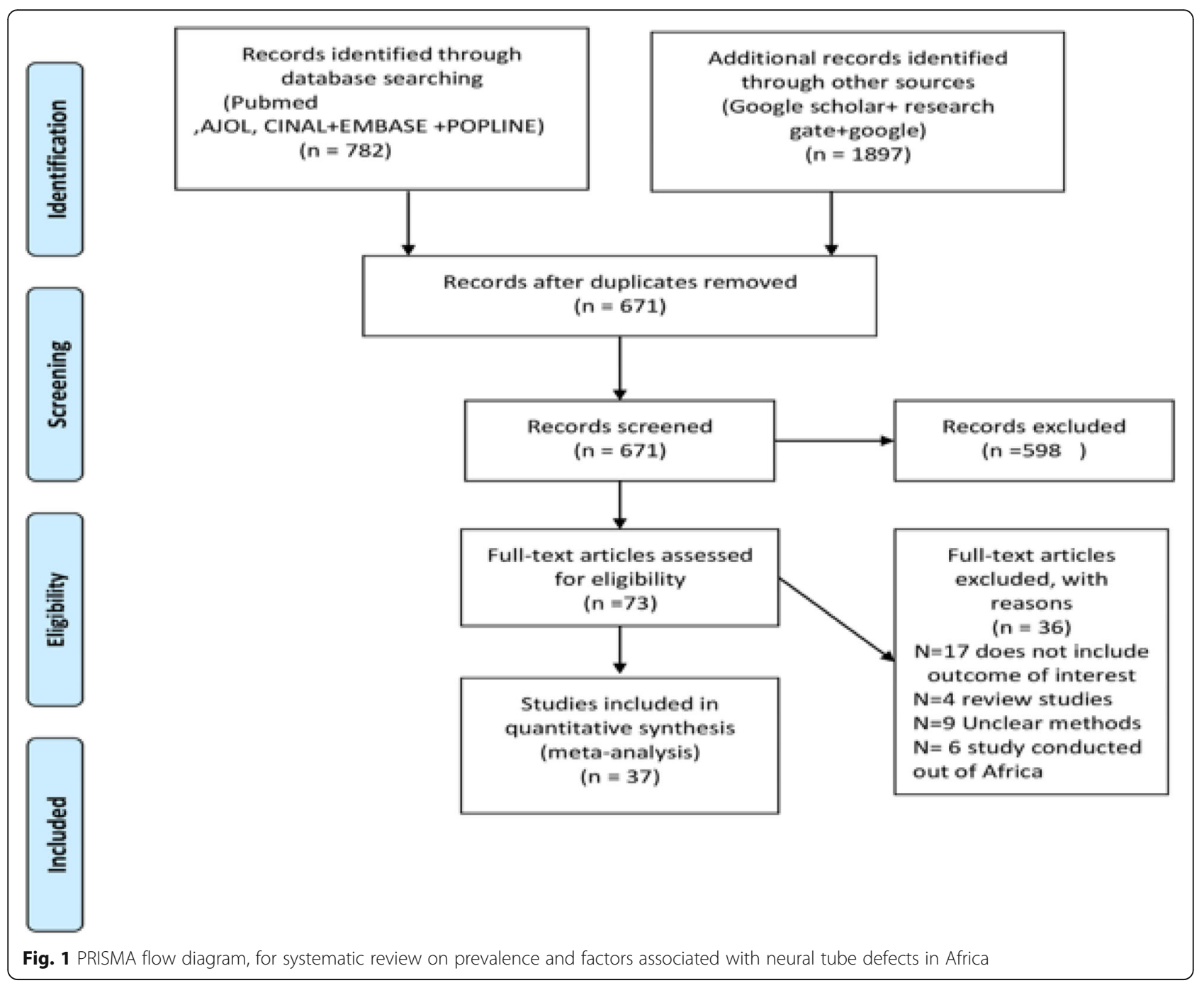

$p<0.001$ ) (Fig. 2). There was significant heterogeneity among the included studies $\left(\mathrm{I}^{2}=100 \%, p\right.$-value $\left.<0.001\right)$. Begg's test showed that there is no statistically significant publication bias with $p$-value $=0.743$ (Fig. 3).

\section{Sub-group analysis of the prevalence of NTDs}

The sub-group analysis by sub-region showed that the prevalence of NTD was highest in the East African sub-region, 84.48 cases of NTDs per 10,000 births (95\% CI: 61.37, 107.54), and the lowest was in Central Africa, 10.20 per 10,000 births (95\% CI: 10.20, 10.20) (Fig. 4).

\section{Prevalence of NTDs by sub-types in Africa}

The meta-analysis was also conducted by sub-type of neural tube defect. In this sub-group, the prevalence of spina bifida (cystica and occulta) was 29.67 cases per 10, 000 births (Fig. 5), and anencephaly was 19.11 cases per 10,000 births (Fig. 6).

\section{Determinants of neural tube defects (NTDs)}

The determinant factors included in this analysis were maternal age, maternal folic acid supplementation before pregnancy and within the first month of pregnancy, paternal consanguineous marriage, previous history of stillbirth, exposure to a pesticide, exposure to radiation, history of alcohol consumption, and sex of the newborn. A separate analysis was conducted for each variable.

\section{Folic acid and neural tube defects}

Six studies [18, 37-40, 51, 52] examined the association between folic acid supplementations before and within the first months of pregnancy. The pooled odds ratio indicated that women who have taken folic acid supplements before pregnancy and within the first month of pregnancy were $60 \%$ less likely to have newborns with neural tube defects (POR, 95\% CI:0.4 (0.19-0.85)). The studies showed high heterogeneity $\left(\mathrm{I}^{2}=78.0 \%\right.$ and $p<0.001)$. Hence a random effect model was employed for final analysis (Fig. 7). 


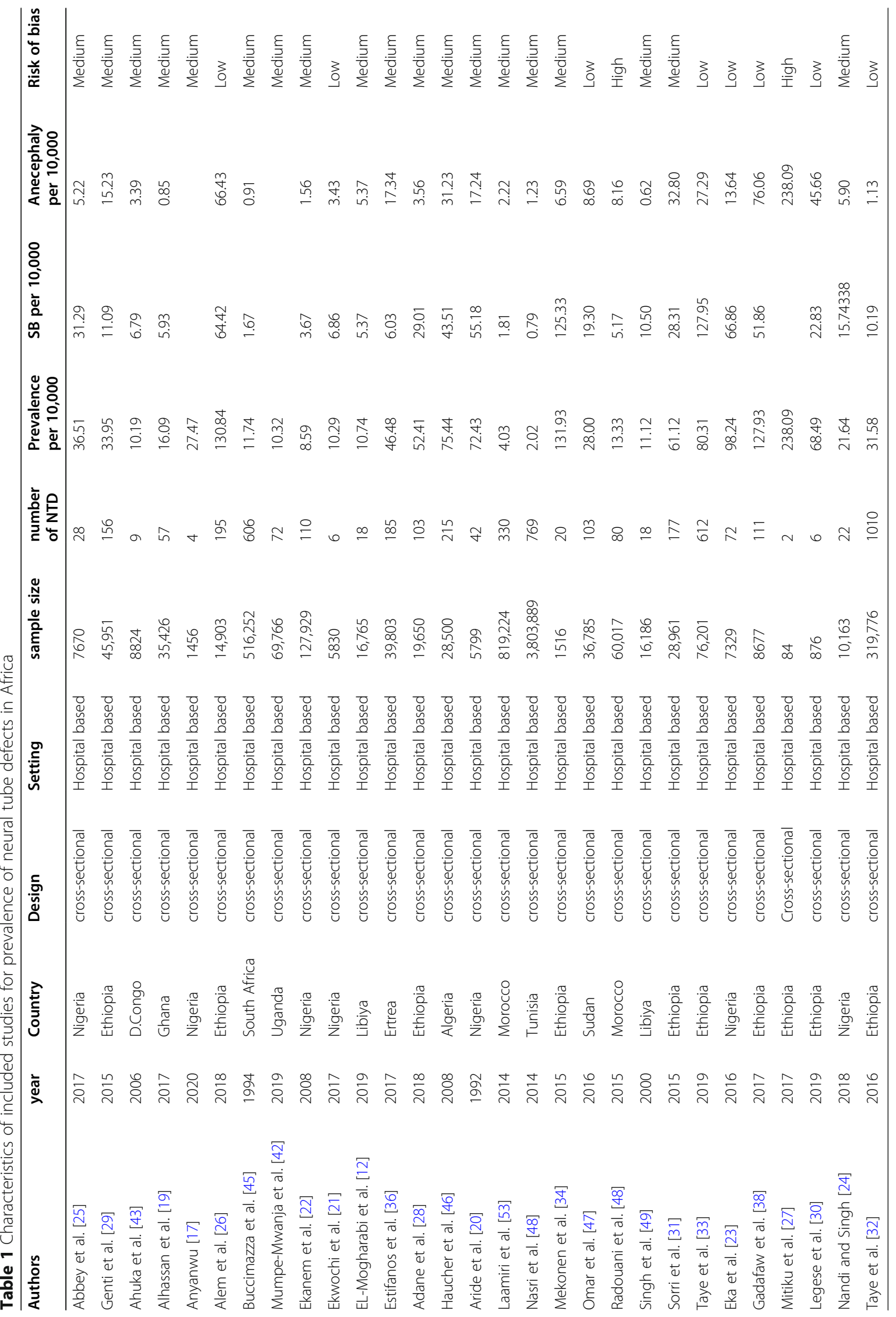




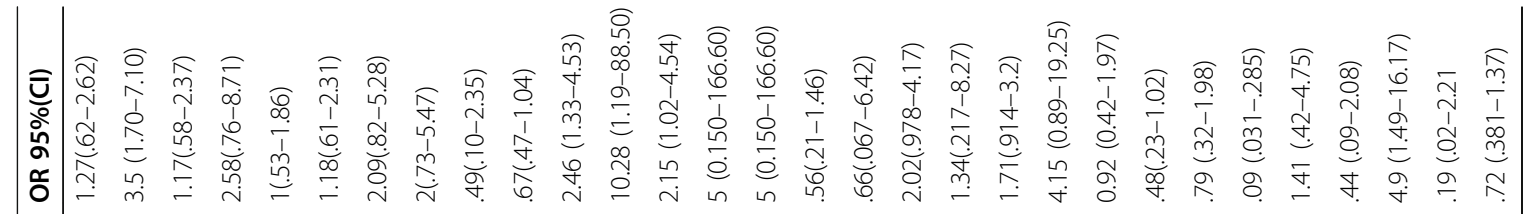

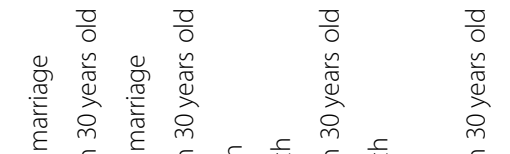

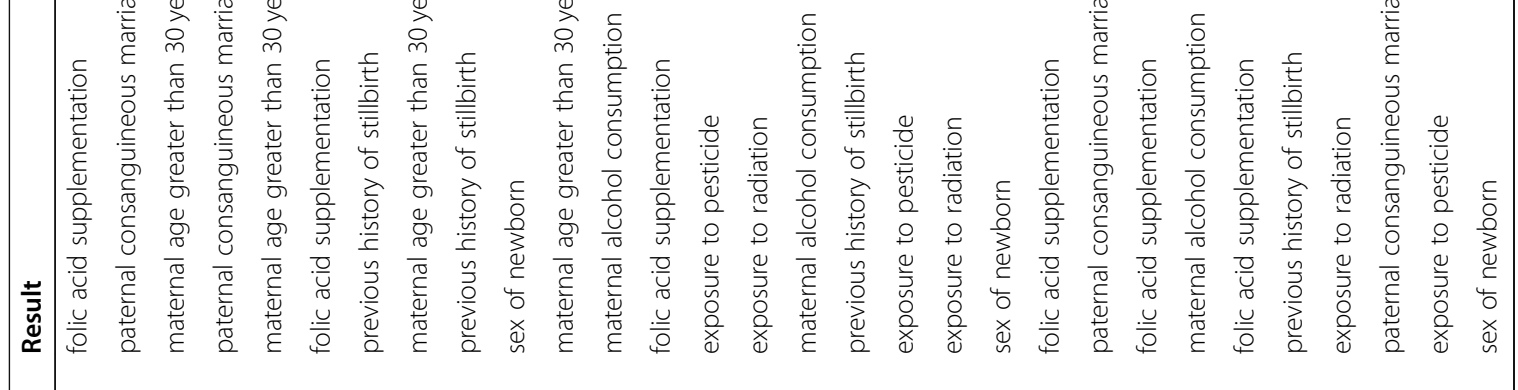

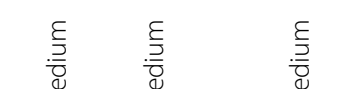

$\frac{\grave{n}}{\check{x}}$

$\frac{\xi}{\frac{5}{5}}$

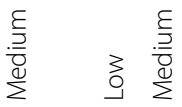

을

ชั้

安

$\frac{\sqrt{2}}{\frac{5}{2}}$

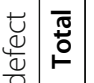

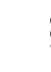

(2)

$\stackrel{n}{n}$

$\stackrel{m}{m} \quad \hat{\sigma}$

$\infty$

$\stackrel{m}{\sim}$ fิ ซึ?

है $\frac{1}{2}$ ये

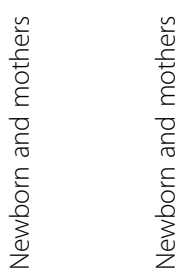

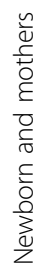

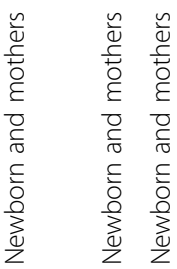

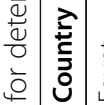

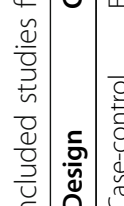

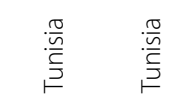

高

高

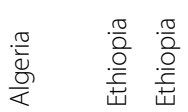

능

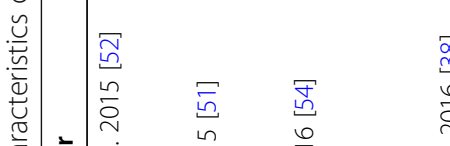

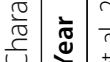

N

N

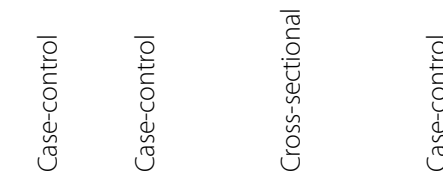

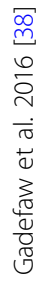

$\frac{. \frac{0}{0}}{. \frac{0}{ \pm}}$

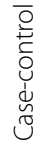

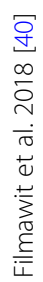

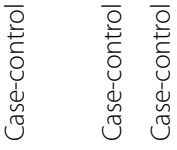

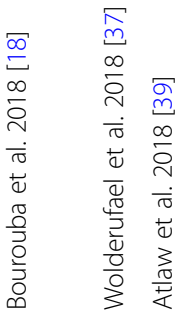




\begin{tabular}{|c|c|c|c|}
\hline \multicolumn{2}{|l|}{ Study } & \multirow{3}{*}{$\begin{array}{l}\text { ES }(95 \% \mathrm{Cl}) \\
36.51(36.50,36.51)\end{array}$} & \multirow{3}{*}{$\begin{array}{l}\% \\
\text { Weight } \\
3.45\end{array}$} \\
\hline ID & & & \\
\hline Abbey et al (2017) & - & & \\
\hline Abebe et al (2015) & - I & $33.95(33.95,33.95)$ & 3.45 \\
\hline Ahuka et al (2006) & - $\quad 1$ & $10.20(10.20,10.20)$ & 3.45 \\
\hline Alhassan et al (2017) & - i & $16.09(16.09,16.09)$ & 3.45 \\
\hline Anyanwu (2020) & - 1 & $27.47(27.47,27.48)$ & 3.45 \\
\hline Berhanu et al (2018) & - & $130.85(130.84,130.85)$ & 3.45 \\
\hline Buccimazza et al (1994) & & $11.74(11.74,11.74)$ & 3.45 \\
\hline Mumpe-Mwanja et al (2019) & - 1 & $10.32(10.32,10.32)$ & 3.45 \\
\hline Doris et al (2008) & - 1 & $8.60(8.60,8.60)$ & 3.45 \\
\hline Ekwochi et al (2017) & - & $10.29(10.29,10.29)$ & 3.45 \\
\hline EL-Mogharabi et al (2019) & - & $10.74(10.74,10.74)$ & 3.45 \\
\hline Estifanos et al (2017) & 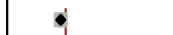 & $46.48(46.48,46.48)$ & 3.45 \\
\hline Adane et al (2018) & - & $52.42(52.42,52.42)$ & 3.45 \\
\hline Haucher et al (2008) & - & $75.44(75.44,75.44)$ & 3.45 \\
\hline Kareem et al (1992) & - & $72.43(72.42,72.43)$ & 3.45 \\
\hline Laamiri et al (2014) & ? & $4.03(4.03,4.03)$ & 3.45 \\
\hline Nasri et al (2014) & 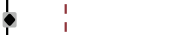 & $2.02(2.02,2.02)$ & 3.45 \\
\hline Mekonen et al (2015) & - & $131.93(131.92,131.93)$ & 3.45 \\
\hline Omar et al (2016) & - 1 & $28.00(28.00,28.00)$ & 3.45 \\
\hline Radouani et al (2015) & - 1 & $13.33(13.33,13.33)$ & 3.45 \\
\hline Singh et al (2000) & - & $11.12(11.12,11.12)$ & 3.45 \\
\hline Sorri et al (2015) & : & $61.12(61.12,61.12)$ & 3.45 \\
\hline Taye et al (2016) & ! & $80.31(80.31,80.31)$ & 3.45 \\
\hline Eka et al (2016) & - & $98.24(98.24,98.24)$ & 3.45 \\
\hline Gadafaw et al (2017) & - & $127.92(127.92,127.93)$ & 3.45 \\
\hline Mitiku et a (2017) & & $\times 238.10(238.09,238.10)$ & 3.45 \\
\hline Legese et al (2019) & $\bullet$ & $68.49(68.49,68.50)$ & 3.45 \\
\hline Nandi and Singh (2018) & - 1 & $21.65(21.65,21.65)$ & 3.45 \\
\hline Taye et al (2016) & - i & $31.58(31.58,31.59)$ & 3.45 \\
\hline Overall (I-squared $=100.0 \%, p=0.000$ ) & 1 & $50.74(48.03,53.44)$ & 100.00 \\
\hline NOTE: Weights are from random effects analysis & & & \\
\hline 1 & & 1 & \\
\hline
\end{tabular}

Fig. 2 Meta-analysis, the prevalence of neural tube defects per 10,000 births in Africa

\section{Paternal consanguineous marriage and neural tube defects}

The association of paternal consanguineous marriage and neural tube defect was examined based on the findings from six studies $[17,18,39,52,54,55]$. The pooled odds ratio indicated that neural tube defects do not differ among parents with and without consanguineous marriages (POR, 95\% CI: $1.42(.62-3.23)$ ). The studies showed moderate heterogeneity $\left(\mathrm{I}^{2}=74.0 \%, p<0.001\right)$. Hence a random effect model was considered for the final analysis (Fig. 8).

\section{Exposure to pesticide and neural tube defects}

This meta-analysis was employed on three studies [32, $33,53]$, and pooled odds ratio was examined. It revealed that women exposed to the pesticide were three times more likely to have newborns with neural tube defects than women who were not exposed to pesticide during pregnancy and within 1 year before pregnancy (POR, 95\% CI: 3.29 (1.04-10.39)). The studies showed low heterogeneity $\left(\mathrm{I}^{2}=35.0 \%\right.$ and $\left.p=0.21\right)$ (Fig. 9). Hence a fixed-effect model was considered to do the final analysis. A funnel plot was symmetrical.

\section{Maternal age and neural tube defects}

The association of maternal age and neural tube defect was examined based on the findings from five studies $[38,40,42,51,54]$. The pooled odds ratio indicated that the odds of neural tube defect are 1.5 times higher among women with an age group greater than 30 years during pregnancy (POR, 95\% CI: 1.47(1.16-1.87)). The heterogeneity test revealed mild heterogeneity $\left(\mathrm{I}^{2}=86 \%\right.$, $p=<0.001)$, and therefore, a random effect model was used in the final analysis (Table 3 ).

\section{Maternal exposure to radiation and neural tube defects}

Three studies examined the association between maternal exposure to pesticides during pregnancy [39, 40, 42]. The pooled estimate showed that women exposed to $\mathrm{x}$ ray radiation were two times more likely to have 


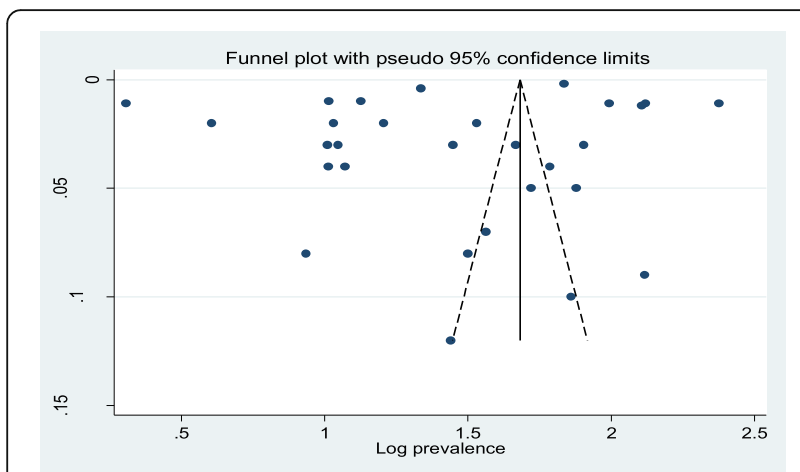

Fig. 3 Funnel plot showing publication bias status of studies included for the meta-analysis on prevalence of neural tube defects in Africa

newborns with neural tube defects than women who were never exposed to $\mathrm{x}$-ray radiation (POR, 95\% CI: $2.34(1.27-4.31))$. The heterogeneity test revealed low heterogeneity $\left(\mathrm{I}^{2}=0 \%, p=0.1\right)$, and therefore a fixed model was assumed in the analysis (Table 3 ).

\section{Maternal alcohol consumption and neural tube defects}

Pooled results of three studies [39, 40, 42] showed that neural tube defect occurrence does not differ among women who consume alcohol and who do not consume alcohol during their pregnancy and 1 year before pregnancy (POR, 95\% CI: $1.3(0.41-4.48)$ ). The heterogeneity test revealed mild heterogeneity $\left(\mathrm{I}^{2}=67 \%, p=0.05\right)$, and therefore a random model was assumed in the analysis (Table 3).

\section{Previous stillbirth and neural tube defects}

Four studies [38-40, 42] have examined the association of the previous stillbirth and neural tube defects. The pooled odds revealed that women who have a previous history of stillbirth were three times more likely to have newborns with neural tube defects than women who have no previous stillbirth [POR, 95\% CI: 3.35 (1.995.65)]. The heterogeneity test revealed high heterogeneity $\left(\mathrm{I}^{2}=86 \%, p=<0.001\right)$ (Table 3$)$, and therefore, a random model was assumed in the analysis.

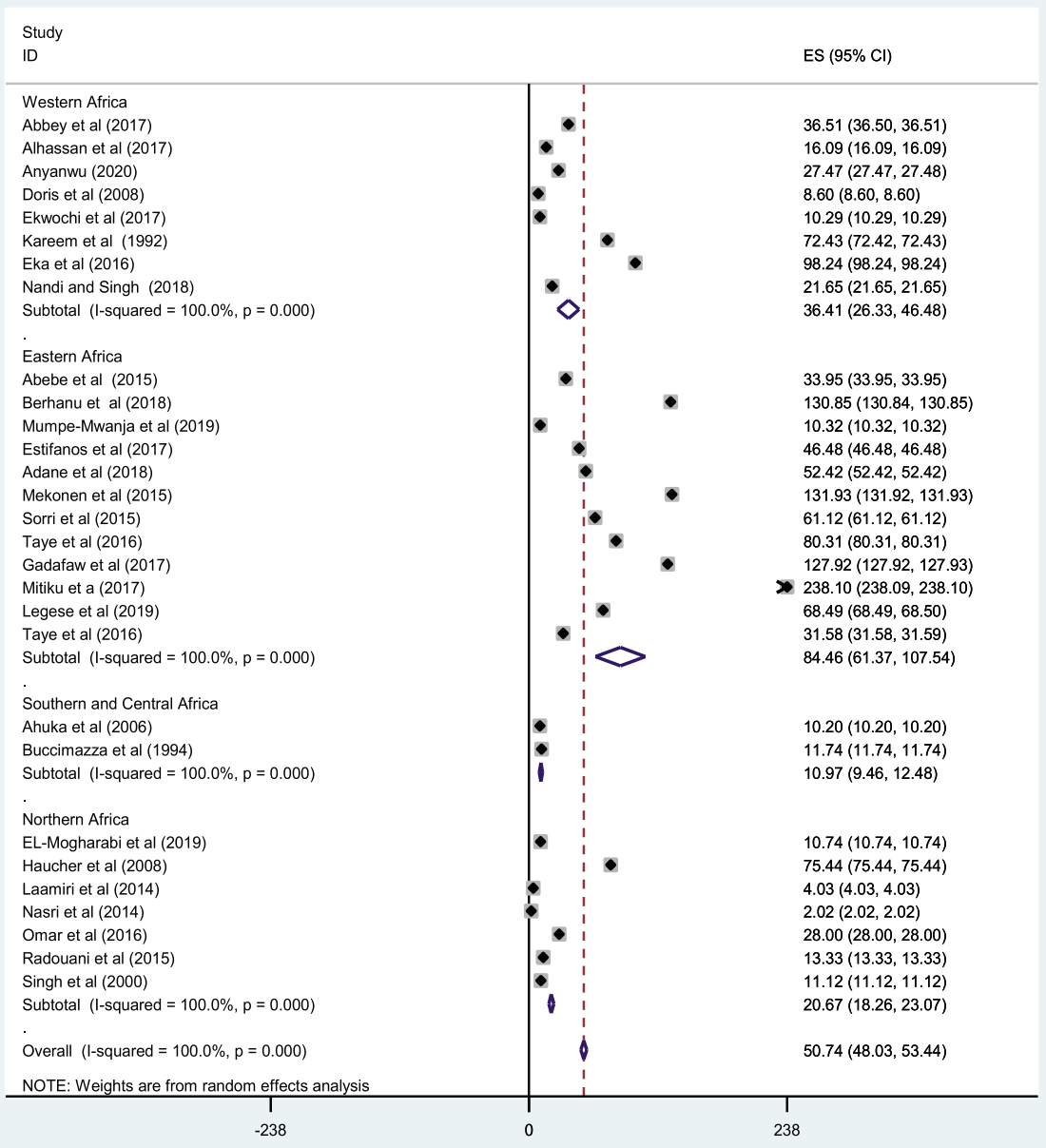

Fig. 4 Sub-group analysis by the regions of African countries, the prevalence of neural tube defects per 10,000 births in Africa 


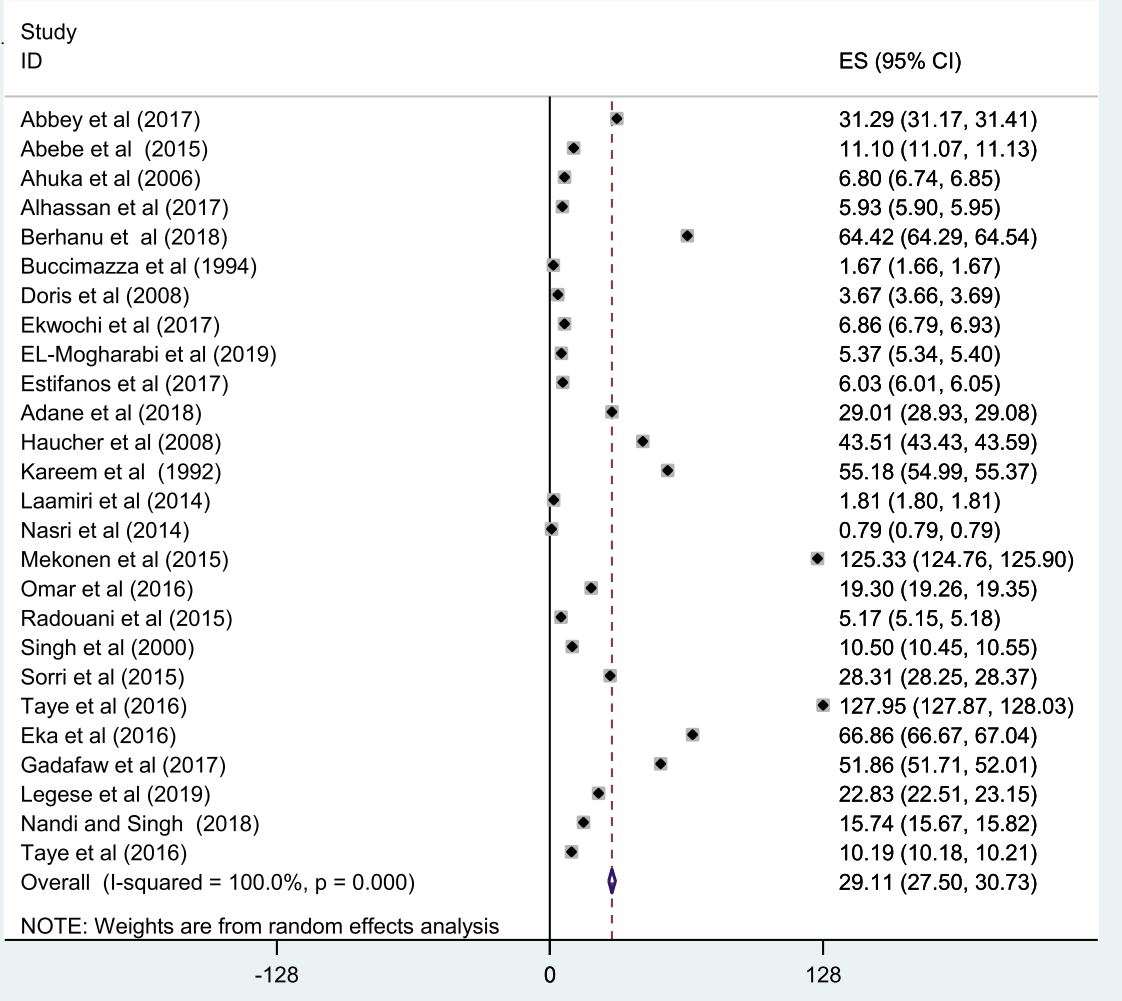

Fig. 5 Meta-analysis, the prevalence of spina bifida per 10,000 births in Africa

\section{Sex of newborn and neural tube defect}

Three studies [38-40] included in the meta-analysis have revealed that there was no difference among male and female newborns on the occurrence of neural tube defects (POR, 95\% CI: $0.86(0.60-1.23))$. The heterogeneity test revealed mild heterogeneity $\left(\mathrm{I}^{2}=43 \%, p=\right.$ $<0.17$ ) (Table 3), and therefore, a fixed-effect model was used in the analysis.

\section{Discussion}

This systematic review and meta-analysis were conducted to estimate the prevalence and determinant factors of neural tube defects (NTDs) in Africa. The pooled prevalence of NTDs in Africa was 50.74 per 10,000 births. This prevalence is higher than a previous review conducted in low and middle-income countries (LMICs) in 2015 , which reported 11.7 per 10,000 births [3]. The previous review included only two studies from the African region, which might underestimate the overall prevalence in the region. Besides, our finding is much higher than reported by a review conducted in India [56] which might be attributable to the geographical and sociodemographic variation of study participants.
The subgroup analysis has shown a higher prevalence of NTD in East African countries with 84.84 cases per 10,000 births which may be due to higher serum folic acid deficiency among reproductive-age women in Eastern Africa countries [57]. A limited number of Eastern Africa countries have the mandatory folic acid fortification of staple food in the African region [58]. A lower prevalence of NTDs was observed in Central and Southern Africa. In this region, the studies included those from Cameroon and South Africa, which have mandatory folic acid fortification that might affect the prevalence of NTDs [59].

This study also tried to identify the most common avoidable factors of neural tube defects in Africa. The present meta-analysis indicated that women who have taken folic acid supplements before pregnancy and/or within the first month of pregnancy were less likely to have newborns with neural tube defects. These findings are in line with a review that showed evidence of decreased risk of NTDs occurring among women who have folic acid supplements [60]. A review study conducted in 2017 by the US task force has revealed the protective effect of folic acid on neural tube defects [61]. The folic acid increases 


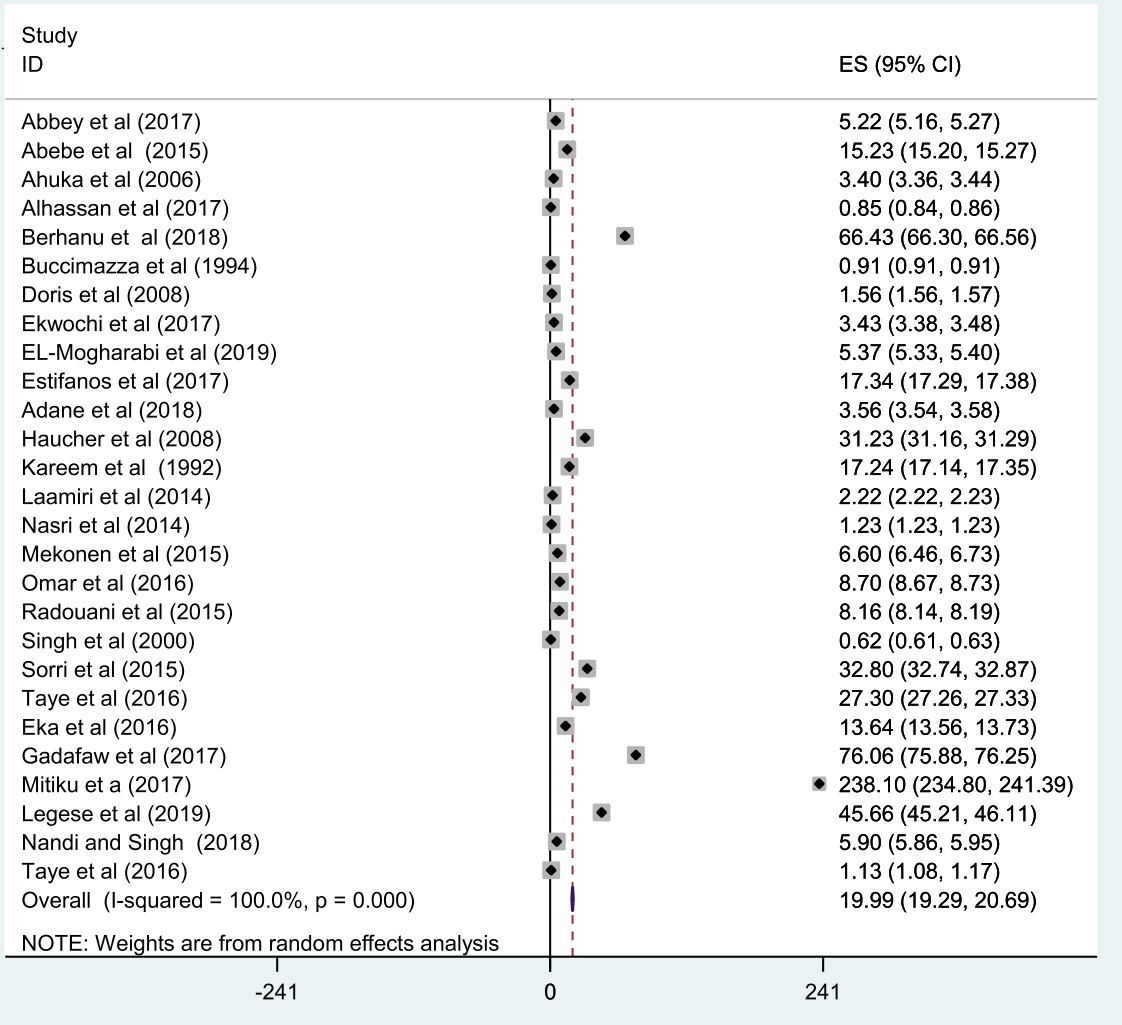

Fig. 6 Meta-analysis, the prevalence of anencephaly per 10,000 births in Africa

neural tube closure and central nervous system development as it has a role in nucleotide synthesis, and folate also engages acute signaling in neurons [60, 62-64].

The findings of this pooled odds ratio indicated that NTD does not differ among parents with and without consanguineous marriages. This finding contradicts with a review conducted in 2010 that has revealed consanguinity as a significant risk of NTDs [65]. The consanguineous marriages will increase autosomal recessive and dominant ending up in neural tube defects [66, 67]. The difference may be due to the presence of limited primary studies investigating the association of NTDs and consanguinity in this review and metaanalysis.

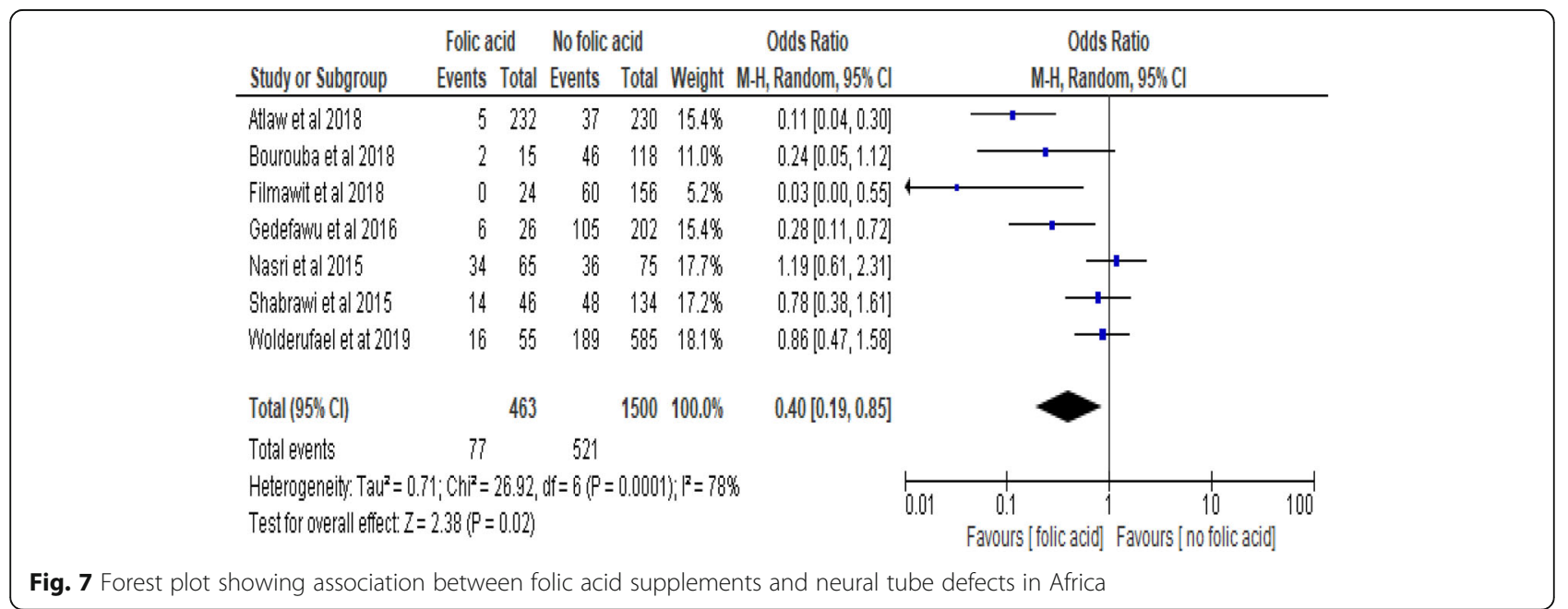




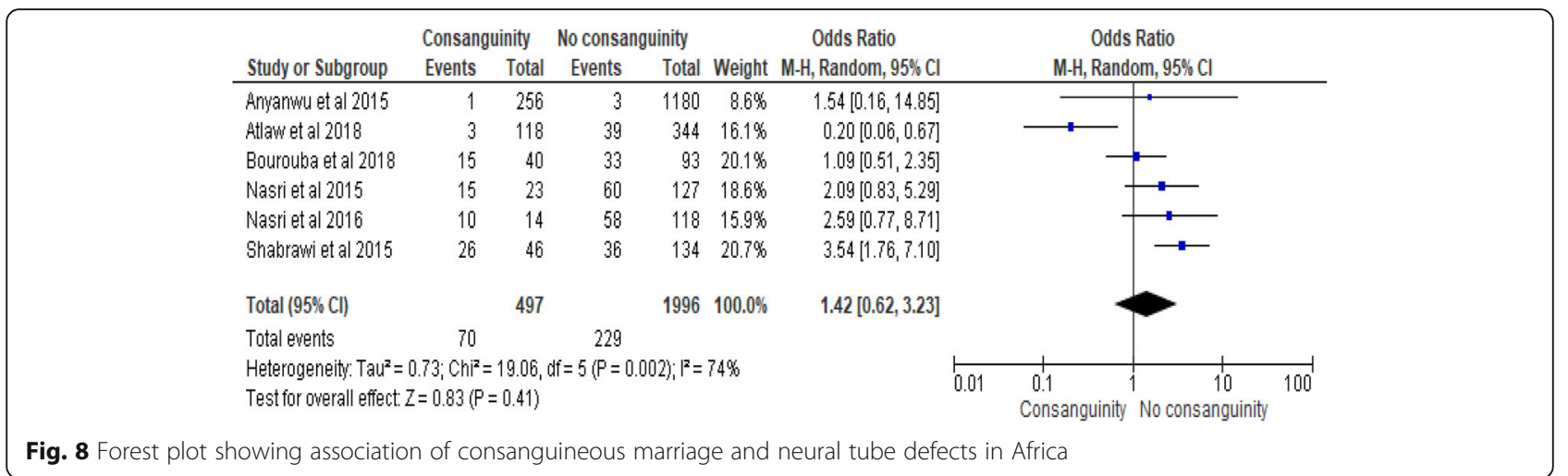

The pooled odds indicated that the odd neural tube defect is 1.5 times higher among women with an age group of greater than 30 years during pregnancy. This observed difference can be explained by the fact that an increase in age will increase the risk of aneuploidy [68, 69]. Besides, a gradual loss of meiotic cohesion during meiosis in oocytes contributes to non-disjunction events leading to a high incidence of aneuploidy [70]. Aneuploidy, in turn, will result in neural tube defects [71].

Women with a history of agricultural pesticide exposure during the first 3 months of pregnancy were three times more likely to give birth to newborns with neural tube defects than those with no history of exposure to a pesticide. This finding is supported by a study conducted in America, where mothers having pesticide exposure were 3 times more likely to have newborns with NTDs [72]. This high risk might be explained by the effect of pesticides on nucleotide synthesis [73, 74]. Pesticide exposure results in impaired development if it occurs in early pregnancy $[75,76]$. Further, organochlorine pesticide increases the risk of NTDs [77], and this pesticide is a commonly used agricultural pesticide in Africa [78]. Since most of the African population are farmers, they are subjected to frequent exposure to agricultural pesticides [77].

The present meta-analysis identified that women with a history of exposure to $\mathrm{x}$-ray radiation during the first 3 months of pregnancy were two times higher odds of having a newborn with a neural tube defect than women with no history of exposure. This observation might be due to $\mathrm{x}$-ray ionization that may result in genetic mutation, which in turn affects DNA methylation, thereby ending up in NTDs [79]. A review conducted in 2015 concluded that low-dose radiation exposure could damage the DNA [80]. Further, radiation will induce neuronal apoptosis even at a low dose was evidenced in developing neocortex [81], which results in apoptotic mutation that causes failure of neural tube closure [81, 82].

Women who have a previous history of stillbirth were three times more likely to have newborns with neural tube defects than women who have no previous stillbirth. This can be explained by the fact that women who have a previous history of NTD have the risk of recurrences in a subsequent pregnancy [83, 84]. The common cause for recurrence of NTDs was low serum folate and chromosomal abnormalities [85]. Further, Neural tube defect was shown to have 25 and 50\% recurrence among autosomal recessive and dominant, respectively [86].

Generally, the burden of NTD is higher in Africa when compared to other regions, and identified factors are avoidable by folic acid fortification and health education provision on the effects of pesticides and ionizing radiation.

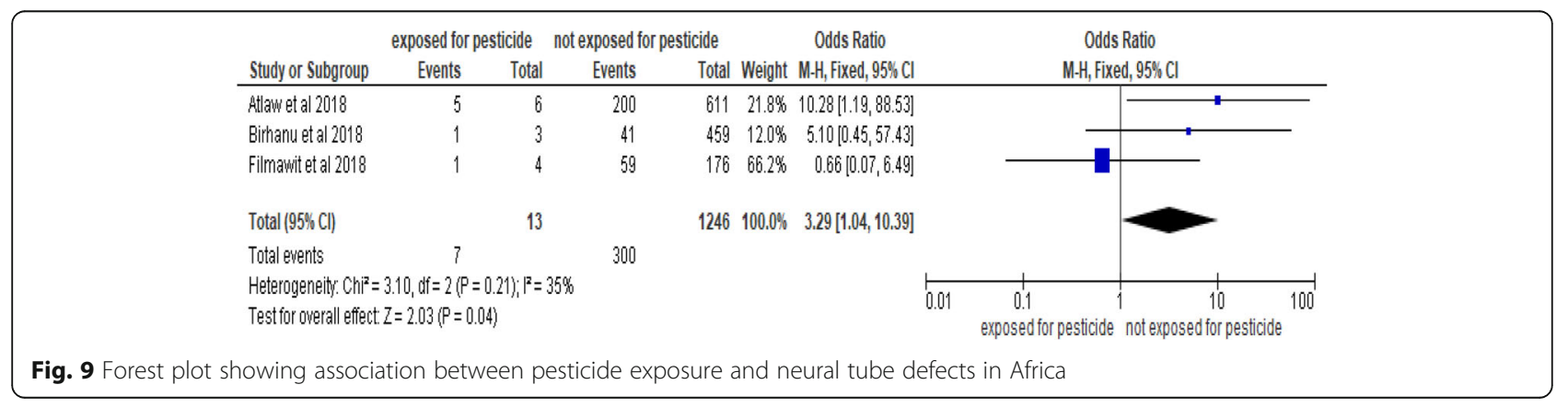


Table 3 Showing relationship of different factors with the neural tube defects in Africa

\begin{tabular}{|c|c|c|c|}
\hline Variables & Pooled odds ratio with $95 \% \mathrm{Cl}$ & $I^{2} \%$ & $p$-value \\
\hline $\mathrm{x}$-ray radiation exposure & $2.34(1.27-4.31)$ & 0 & $P<0.001$ \\
\hline Alcohol consumption & $1.3(0.41-4.48)$ & 67 & 0.05 \\
\hline History of stillbirth & $3.35(1.99-5.65)$ & 86 & 0.001 \\
\hline Sex of newborn & $0.86(0.60-1.23)$ & 43 & 0.17 \\
\hline Age & $1.47(1.16-1.87)$ & 85 & $p<0.001$ \\
\hline
\end{tabular}

\section{Limitations}

There are limited original studies conducted in central and southern regions of Africa which may affect the overall burden of NTDs in Africa. There were few primary studies conducted on factors associated with NTDs, which may affect the representation of Africa. The original studies included in this meta-analysis did not report the dose, duration, and timing of exposure to $\mathrm{x}$-ray radiation that may affect the strength of association between NTDs and $\mathrm{x}$-ray radiation.

\section{Conclusion}

This meta-analysis and systematic review identified that there is a high burden of NTDs in Africa. About five in thousand newborns are affected in Africa, while nine per thousand newborns are affected in Eastern Africa. Before and during early pregnancy, folic acid supplementation was identified as protective factors, while the previous history of stillbirth, exposure to a pesticide, and x-ray radiation were factors associated with NTDs in Africa.

Most of the factors identified in this study were avoidable; therefore, folic acid fortification of staple foods and considering folic acid supplementation of reproductiveage women may significantly reduce a high burden of NTDs in Africa. Further, avoiding pesticide and x-ray exposures during the first trimester of pregnancy may also contribute to the reduction of NTDs occurrence. In addition, we recommend original studies to be conducted in the Central and Southern African regions.

\section{Abbreviations}

Cl: Confidence Interval; JBI: Joanna Briggs Institute; PRISMA: Preferred Reporting System for Meta-Analysis and Systematic Review; NTDs: Neural Tube Defects; POR: Pooled Odds Ratio; WHO: World Health Organization

\section{Supplementary Information}

The online version contains supplementary material available at https://doi. org/10.1186/s12884-021-03848-9.

Additional file 1. PRISMA checklist.

Additional file 2. Search stratagy and terms used to find articles from databeses.

Additional file 3. Risk of bias assesement tool for cross-sectional studies. Additional file 4. Risk of bias assesement tool for case-control studies. Additional file 5. Data extraction tool for magnitude of NTDs.
Additional file 6. Data extraction tool for associated factors with NTDs.

\section{Acknowledgments}

We sincerely thank all the authors of original articles who have responded timely to our queries through emails.

\section{Authors' contributions}

DA: Conceptualize, study protocol, data extraction, and analysis, and write the original draft of the manuscript. DA, YT, BS, KS, DS, and HG conducted study design, literature review, and statistical analysis of the review. DA, BS, and KS conducted a critical appraisal and data extraction. DA wrote the original draft of the manuscript. ZT, YT, YT, BS, KS, DS, HG, and VKC critically revised the manuscript. VKC edited the final version of the draft. All authors read and approved the final version before submission.

\section{Funding}

Nil

\section{Availability of data and materials}

The part of the data analyzed during this study is included in this manuscript. Other data will be available from the corresponding author upon a reasonable request.

\section{Declarations}

Ethics approval and consent to participate

Not applicable.

\section{Consent for publication}

Not applicable.

Competing interests

The authors declare no competing interests in this work.

\section{Author details}

${ }^{1}$ Department of Human Anatomy, School of Medicine, Goba Referral Hospital, Madda Walabu University, Goba, Ethiopia. ²Department of Public Health, School of Health Science, Goba Referral Hospital, Madda Walabu University, Goba, Ethiopia. ${ }^{3}$ Department of Midwifery, School of Health Science, Goba Referral Hospital, Madda Walabu University, Goba, Ethiopia. ${ }^{4}$ Department of physiology, School of Medicine, Goba Referral Hospital, Madda Walabu University, Goba, Ethiopia. ${ }^{5}$ College of Medicine and Health Sciences, Dire Dawa University, Dire Dawa, Ethiopia. 'Department of Medicine, Faculty of Medicine, University of Toronto, Toronto, ON M5S 1A8, Canada.

Received: 14 December 2020 Accepted: 5 May 2021

Published online: 14 June 2021

\section{References}

1. Sadler TW. Langman's Medical Embryology 11th Edition. 2011. 294-305 p.

2. Botto L, Moore CYM, Ricson DAE. Neural tube defect. New Engl J Med Neural. 1999;341(20):1509-19. https://doi.org/10.1056/NEJM1 99911113412006

3. Lo A, Polšek D, Sidhu S. Estimating the burden of neural tube defects in low- and middle-income countries. J Glob Health. 2014;4(1):1-9. 
4. Zaganjor I, Sekkarie A, Tsang BL, Williams J, Razzaghi H, Mulinare J, et al. Describing the prevalence of neural tube defects worldwide: a systematic literature review. PLoS One. 2016;11(4):1-31.

5. Lawal TA, Adeleye AO. Determinants of folic acid intake during preconception and in early pregnancy by mothers in Ibadan. Nigeria. 2014; 8688:1-6.

6. Flores AL, Vellozzi C, Valencia D, Sniezek JE. Global burden of neural tube defects, risk factors, and prevention. Indian J Community Heal. 2014;26(5):3-5.

7. Githuku JN, Azofeifa A, Valencia D, Ao T, Hamner H, Amwayi S, et al. Assessing the prevalence of spina bifida and encephalocele in a Kenyan hospital from 2005-2010: implications for a neural tube defects surveillance system. Pan Afr Med J. 2014;18:60.

8. Blencowe H, Kancherla V, Moorthie S, Darlison MW, Modell B. Estimates of global and regional prevalence of neural tube defects for 2015: a systematic analysis. Ann NewYork Acad Sci. 2015:1-16.

9. Dessie MA, Zeleke EG, Workie SB, Berihun AW. Folic acid usage and associated factors in the prevention of neural tube defects among pregnant women in Ethiopia: cross-sectional study. BMC Pregnancy Childbirth. 2017; 17(1):1-8.

10. Kishimba R, Mpembeni R. Sciences A. Factors associated with major structural birth defects among newborns delivered at Muhimbili National Hospital and Municipal Hospitals in Dar Es Salaam, Tanzania 2011-2012; 2015.

11. Tsehay B, Shitie D, Lake A, Abebaw E, Taye A, Essa E. Determinants and seasonality of major structural birth defects among newborns delivered at primary and referral hospital of East and West Gojjam zones, Northwest Ethiopia. BMC Res Notes [Internet]. 2019;12(495):1-6. Available from: https:// doi.org/10.1186/s13104-019-4541-4.

12. El- Moghrabi H, Fym Z, Ne E-, Khalil E. International Journal of Stem Cell \& Regenerative Medicine Congenital Malformations and its Relation with Consanguineous Marriages at Benghazi. Pubtexto Publ. 2019;1(1).

13. Nelson A. Folates for reduction of risk of neural tube defects: using oral contraceptives as a source of folate. Open Access J Contracept. 2011;137.

14. Prospero International prospective register of systematic reviews. The magnitude and associated factors of neural tube defects in sub-Saharan Africa: a systematic review and meta-analysis. NHS. 2020;1-10.

15. Moher D, Shamseer L, Clarke M, Ghersi D, Liberati A, Petticrew M, et al. Preferred reporting items for systematic review and meta-analysis protocols ( PRISMA-P) 2015 statement. BMC. 2015;4(1):1-9.

16. JBI. Checklist for Analytical Cross Sectional Studies [Internet]. JBI critical apraisal tools for use in JBI systematic reviews. 2017. Available from: http:// joannabriggs.org/research/critical-appraisal-tools.htmlwww.joannabriggs.

17. Anyanwu LC, Danborno B, Hamman WO. The prevalence of neural tube defects in live born neonates in Kano, North-western Nigeria. Sub-Saharan African J Med. 2015;2(3):105-9. https://doi.org/10.4103/2384-5147.164417.

18. Bourouba R, Houcher B, Akar N. The Egyptian journal of medical human genetics risk factors of neural tube defects : a reality of Batna region in Algeria. Egypt J med hum genet [internet]. 2018;19(3):225-9. Available from: https://doi.org/10.1016/j.ejmhg.2017.10.003, 2018

19. Alhassan A, Adam A, Nangkuu D. Prevalence of neural tube defect and hydrocephalus in northern Ghana. J Med Biomed Sci. 2017;6(1):18-23.

20. Airede Kl. Neural tube defects in the Middle Belt of Nigeria. J Trop Pediatr. 1992;38(1):27-30. https://doi.org/10.1093/tropej/38.1.27.

21. Ekwochi U, Asinobi IN, Chidiebere D, Osuorah I, Ndu IK, Ifediora C, et al. Pattern of congenital anomalies in newborn : a 4-year surveillance of newborns delivered in a tertiary healthcare facility in the. J ofTropical Pediatr. 2018;64(4):304-11. https://doi.org/10.1093/tropej/fm×067.

22. Ekanem TB, Okon DE, Akpantah AO, Mesembe OE, Eluwa MA, Ekong MB. Prevalence of congenital malformations in Cross River and Akwa lbom states of Nigeria from 1980-2003. Japanese Teratol Soc. 2008;48:167-70.

23. Eke CB, Uche EO, Maduabuchi J, Chinawa I, Obi E, Obu HA, et al. Epidemiology of congenital anomalies of the central nervous system in children in Enugu, Nigeria: a retrospective study. Ann Afr Med. 2016;15(3): 126-32. https://doi.org/10.4103/1596-3519.188892.

24. Nnadi DC, Singh S. The prevalence of neural tube defects in North-West Nigeria. Artic Saudi J Heal Sci. 2016;5:6.

25. Abbey M, Oloyede OA, Bassey G, Kejeh BM, Otaigbe BE, Opara PI, et al. Prevalence and pattern of birth defects in a tertiary health facility in the Niger Delta area of Nigeria. Int J Women's Heal. 2017;9:115-21. https://doi. org/10.2147/IJWH.S108905.
26. Alem B, Id B, Welderufael AL, Berhe Y, Magana T, Mulugeta A, et al. High burden of neural tube defects in Tigray, Northern Ethiopia : Hospital-based study. PLoS One. 2018;13(11):1-10.

27. Mitiku T. Pilot Study to Assess the AntenatalPoint Prevalence of Neural Tube Defects and Associated Factors in Pregnant Woman Attending ANC in Ghandi Memorial Hospital in Addis Ababa Ethiopia. preprint. 2017;

28. Adane F, Seyoum G. Prevalence and associated factors of birth defects among newborns at referral hospitals in Northwest Ethiopia. Ethiop J Heal Dev. 2018;32(3)

29. Geneti SA. Prevalence and patterns of birth defects among newborns in Southwestern Ethiopia : Retrospective study. preprint. 2015;1-20.

30. Legesse A. Assessment Of Prevalence, Types and associated Risk Factors of Neural Tube Defects in Pregnant Women Visiting Health Centers in Addis Ababa. preprint. 2019;

31. Sorri G, Mesfin E. Patterns of Neural Tube Defects at Two Teaching Hospitals In Addis Ababa, Ethiopia A Three Years Retrospective Study Patterns of Neural Tube Defects at Two Teaching Hospitals In , Ethiopia a three years retrospective study. Ethiop J Heal Dev. 2018;53:3

32. Taye M, Afework M, Fantaye W, Diro E, Worku A. Magnitude of Birth Defects in Central and Northwest Ethiopia from 2010-2014: A Descriptive Retrospective Study. 2016;76:1-12.

33. Taye M, Afework M, Fantaye W, Diro E, Worku A. Congenital anomalies prevalence in Addis Ababa and the Amhara region, Ethiopia : a descriptive cross-sectional study. BMC Pediatr. 2019;19(234):1-11.

34. Mekonen HK, Nigatu B, Lamers WH. Birth weight by gestational age and congenital malformations in northern Ethiopia. BMC Pregnancy Childbirth. 2015;15(76):1-8.

35. Ethiopia- SW. Assessment of Adverse Birth Outcomes and Associated Factors among Diabetic Pregnant Mothers Who Delivered at Mettu Karl Hospital , Illubabor Zone. Internal Medicine : Open Access. 2019:9(300):1-10.

36. Estifanos D, Adgoy ET, Sereke D, Zekarias B, Marzolf S, Tedla K. The Prevalence, Trend, and Associated Demographic Factors of Neural Tube Defects at Orotta National Referral Maternity Hospital , Asmara : Retrospective Record Review Study. Sci J Public Heal. 2017:5(6):452-6. https://doi.org/10.11648/j.sjph.20170506.17.

37. Welderufael, Alem B, Berhe Y, Magana T. Nutritional status among women whose pregnancy outcome was afflicted with neural tube defects in Tigray region of Ethiopia. Brain Dev [Internet]. 2019:41(5):406-12. Available from: https://doi.org/10.1016/j.braindev.2018.12.005

38. Gedefaw A, Teklu S, Tadesse BT. Magnitude of neural tube defects and associated risk factors at three teaching hospitals in Addis Ababa. Ethiopia Hindawi Biomed Reasearch Int. 2018;2018.

39. Atlaw D, Worku A, Taye M, Woldeyehonis D, Muche A. Journal of Pregnancy and Child Health Neural Tube Defect and Associated Factors in Bale Zone Hospitals. J Pregnancy Child Heal. 2019;6:3.

40. Fimawit A. Determinants of neural tube defect among children at Zewditu memorial hospital. Addis Abeba: Ethiopia case control study. ADDIS ABABA Univ; 2018.

41. Mwanri AW, Kinabo J, Ramaiya K, Feskens EJM. Prevalence of gestational diabetes mellitus in urban and rural Tanzania. Diabetes Res Clin Pract [Internet] 2013;103(1):71-8 Available from: https://doi.org/10.1016/j.diabres.2013.11.021.

42. Birhane A, Leul A, Berhe Y, Magana T. Maternal risk factors associated with neural tube defects in Tigray regional state of Ethiopia. Brain dev [internet]. 2019;41(1):11-8. Available from: https://doi.org/10.1016/j.braindev.2018.07. 013, 2019.

43. Mumpe-mwanja D, Barlow-mosha L, Williamson D, Valencia D, Serunjogi R, Kakande A, et al. A hospital-based birth defects surveillance system in Kampala, Uganda. BMC Pregnancy Childbirth. 2019;19(372):1-9.

44. Ahuka OL, R.M.Toko, F.U.Omanga, B.J.Tshimpagna. congenital malformation in north eastern democratic republic of Congo during civil war. EAST AFRI CAN MEDIAL J. 2006:95-9.

45. Buccimazza SS, Molteno CD, Dunne T, Viwoen DL, Paediatrics D, B CHSS, et al. Prevalence of Neural Tube Defects in Cape Town, South Africa. wiley liss,inc. 1994:50:194-9.

46. Houcher B, Bourouba R, Djabi F, Houcher Z. The Prevalence of Neural Tube Defects in Sétif University Maternity Hospital , Algeria-3 Years Review ( 2004-2006). Pteridines. 2008;19(1):12-8. https://doi.org/10.1515/pteridines.2 008.19.1.12.

47. Omer IM, Abdullah OM, Mohammed IN, Abbasher LA. Research: prevalence of neural tube defects Khartoum, Sudan august 2014-July 2015. Scientifica (Cairo). 2020;2020:1-12. 
48. Radouani MA, Chahid N, Benmiloud L, Ammari L El, Kharbach A, Rjimati L, et al. Prevalence of Neural Tube Defects : Moroccan Study 2008-2011. Open J Pediatr. 2015;(September):248-55.

49. Singh A-s. Major congenital anomalies at birth in benghazi libyan arab jamahiriya 1995. East Mediterr Heal J. 2000;6:1.

50. Natamba BK, Namara AA, Nyirenda MJ. Burden, risk factors and maternal and offspring outcomes of gestational diabetes mellitus ( GDM ) in subSaharan Africa ( SSA ): a systematic review and meta-analysis. BMC Pregnancy Childbirth. 2019;19(450):1-11.

51. Nasri K, Kacem M, Fradj B, Touati A, Aloui M, Jemaa N Ben, et al. Association of Maternal Homocysteine and Vitamins Status with the Risk of Neural Tube Defects in Tunisia : A Case - Control Study. wiley Period. 2015;

52. El-shabrawi MH, Kamal NM, Elhusseini MA, Hussein L, Abdallah E, Abdallah $A$, et al. Folic acid intake and neural tube defects : two Egyptian centers experience. Medicine (Baltimore). 2015:94(37):1-7.

53. Laamiri FZ. Prevalence of Neural Tube Closure Defects And The Oro-Facial Clefts, During Three Consecutive Years (2012-2014) In 20 public hospitals in Morocco. World J Pharm Res. 2017;6:3

54. Nasri K, Fradj MK Ben, Feki M, Kaabechi N, Sahraoui M, Masmoudi A, et al. Maternal 25-hydroxyvitamin D level and the occurrence of neural tube defects in Tunisia. Int J Gynecol Obstet [Internet]. 2016;1-4. Available from: https://doi.org/10.1016/j.ijgo.2016.01.014

55. Nasri K, Kacem M, Fradj B, Hamdi T, Aloui M, Véronique $M$, et al. Epidemiology of neural tube defect subtypes in Tunisia, 1991-2011. Pathol -- Res Pract [Internet] 2014; Available from: https://doi.org/10.1016/j.prp.2 014.06.027

56. Allagh KP, Shamanna BR, Murthy GVS, Ness AR. Birth prevalence of neural tube defects and orofacial clefts in India : a systematic review and metaanalysis. PLoS One. 2015;10(3):1-15.

57. Bationo F, Songré-Ouattara LT, Hama-Ba F, Baye K, Hemery YM, Parkouda C, et al. Folate status of women and children in Africa-current situation and improvement strategies. Food rev Int [internet]. 2020;36(1):1-14. Available from: https://doi.org/10.1080/87559129.2019.1608558, 2020.

58. Mkambula P, Mbuya MNN, Rowe LA, Sablah M, Friesen VM, Chadha $M$, et al The unfinished agenda for food fortification in low- and middle-income countries: quantifying Progress. Gaps and Potential Opportunities MDPI. 2020;12(354):1-19.

59. Wald NJ, Morris JK, Blakemore C. Public health failure in the prevention of neural tube defects: Time to abandon the tolerable upper intake level of folate. Public Health Rev. 2018:39(2)

60. Imbard A, Benoist JF, Blom HJ. Neural tube defects, folic acid and methylation. Int J Environ Res Public Health. 2013;10(9):4352-89. https://doi. org/10.3390/ijerph10094352.

61. Viswanathan M, Treiman KA, Kish-doto J, Middleton JC. Folic acid supplementation for the prevention. JAMA. 2017;317(2):190-203. https://doi. org/10.1001/jama.2016.19193.

62. Balashova OA, Visina O, Borodinsky LN. Folate action in nervous system development and disease. Dev Neurobiol. 2018;78(4):391-402. https://doi. org/10.1002/dneu.22579.

63. Reynolds EH. Benefits and risks of folic acid to the nervous system. J Neurol Neurosurg Psychiatry. 2002;72(5):567-71. https://doi.org/10.1136/ jnnp.72.5.567.

64. Wang L, Wang F, Guan J, Le J, Wu L, Zou J, et al. Relation between hypomethylation of long interspersed nucleotide elements and risk of neural tube defects. Am J Clin Nutr. 2010;91(5):1359-67. https://doi.org/10.3 945/ajcn.2009.28858

65. Brotherton $\mathrm{H}$, Jones $U$, Pelaez $\mathrm{N}$, Rodriquez $\mathrm{O}$. A review of neural tube defects at a tertiary neonatal unit in a low-income country with discussion of management challenges in a resource poor setting. Arch Dis Child. 2010; 95(Suppl 1):A63.2-A63. https://doi.org/10.1136/adc.2010.186338.140.

66. Chen CP. Syndromes, disorders and maternal risk factors associated with neural tube defects (VII). Taiwan J Obstet Gynecol [Internet]. 2008:47(3):27682 Available from: https://doi.org/10.1016/S1028-4559(08)60124-2.

67. Lynch SA. Non-multifactorial neural tube defects. Am J Med Genet - Semin Med Genet. 2005;135 C (1):69-76.

68. Chiang T, Schultz RM, Lampson MA. Meiotic origins of maternal age-related aneuploidy. Biol Reprod. 2012;86(1):1-7. https://doi.org/10.1095/ biolreprod.111.094367.

69. Hassold T, Hunt P. Maternal age and chromosomally abnormal pregnancies. Curr Opin Pediatr. 2009;21(6):703-8. https://doi.org/10.1097/MOP.0b013e32 8332c6ab.
70. Kurahashi H, Tsutsumi M, Nishiyama S, Kogo H, Inagaki H, Ohye A. Molecular basis of maternal age-related increase in oocyte aneuploidy. Congenit Anom (Kyoto). 2012;52:8-15.

71. Chen CP. Chromosomal abnormalities associated with neural tube defects (I): full aneuploidy. Taiwan J Obstet Gynecol. 2007;46(4):325-35. https://doi. org/10.1016/S1028-4559(08)60002-9.

72. Brender JD, Felkner M, Suarez L, Canfield MA, Henry JP. Maternal pesticide exposure and neural tube defects in Mexican Americans. Ann Epidemiol. 2010;20(1):16-22. https://doi.org/10.1016/j.annepidem.2009.09.011.

73. Noll L. Campbell, PharmDa, Fred Unverzagt, PhDe, Michael a. LaMantia, MD, MPHb, Babar a. khan, MD, MSb and Malaz a. Boustani, MD MPH. Organophosphate pesticide exposure and differential genome- wide DNA methylation. Physiol Behav. 2017;176(1):139-48.

74. Van Der Plaat DA, De Jong K, De Vries M, Van Diemen CC, Nedeljkovic I, Amin $\mathrm{N}$, et al. Occupational exposure to pesticides is associated with differential DNA methylation. Occup Environ Med. 2018;75(6):427-35. https://doi.org/10.1136/oemed-2017-104787.

75. Islam A, Malik MF. iMedPub journals toxicity of pesticides on CNS neurotoxicity types of toxicity with respect to exposure. J Toxicol Anal. 2018;1(7):1-6.

76. Guy BP. Uses and misuses of agricultural pesticides in Africa: neglected public health threats for workers and population. Itech open. 2019:1-14.

77. Taiwo AM. A review of environmental and health effects of organochlorine pesticide residues in Africa. Chemosphere [internet]. 2019;220:1126-40. Available from: https://doi.org/10.1016/j.chemosphere.2019.01.001.

78. Gleason KM. Hermann Joseph Mullers Study of X-rays as a Mutagen. enbryo Proj. 1946;6-9.

79. Katsura M, Cyou-Nakamine H, Zen Q, Zen Y, Nansai H, Amagasa S, et al. Effects of low-dose radiation on human neural progenitor cells. Sci Rep. 2016;6(October 2015):1-12

80. Cecconi F, Piacentini M, Fimia GM. The involvement of cell death and survival in neural tube defects: a distinct role for apoptosis and autophagy? Cell Death Differ. 2008;15(7):1170-7. https://doi.org/10.1038/cdd.2008.64.

81. Oria M, Duru S, Figueira RL, Scorletti F, Turner LE, Fernandez-Alonso I, et al. Cell necrosis, intrinsic apoptosis and senescence contribute to the progression of exencephaly to anencephaly in a mice model of congenital chranioschisis. Cell Death Dis [Internet]. 2019;10(721). Available from: https:// doi.org/10.1038/s41419-019-1913-6

82. Cuckle HS. Recurrence risk of neural tube defects following a miscarriage. Prenat Diagn. 1983;3(4):287-9. https://doi.org/10.1002/pd.1970030404.

83. Liu J, Li Z, Greene NDE, Li H, Ren A. The recurrence risk of neural tube defects (NTDs) in a population with high prevalence of NTDs in northern China. Oncotarget. 2017:8(42):72577-83. https://doi.org/10.18632/oncota rget.19890.

84. Otto LDB, Moore C. Ynthia a, Houry M uin JK, Rickson D avid E. neural tube defects. N Engl J Med. 1999:341(20):1509-19.

85. Seidahmed MZ, Abdelbasit OB, Shaheed MM, Alhussein KA, Miqdad AM, Samadi AS, et al. Genetic, chromosomal, and syndromic causes of neural tube defects. Saudi Med J. 2014;35:S49-56.

86. Yin $S$, Sun $Y, Y u$ J, Su Z, Tong $M$, Zhang $Y$, et al. Prenatal exposure to organochlorine pesticides is associated with increased risk for neural tube defects. Sci Total environ [internet]. 2021;770:145284. Available from: https:// doi.org/10.1016/j.scitotenv.2021.145284

\section{Publisher's Note}

Springer Nature remains neutral with regard to jurisdictional claims in published maps and institutional affiliations.

Ready to submit your research? Choose BMC and benefit from:

- fast, convenient online submission

- thorough peer review by experienced researchers in your field

- rapid publication on acceptance

- support for research data, including large and complex data types

- gold Open Access which fosters wider collaboration and increased citations

- maximum visibility for your research: over $100 \mathrm{M}$ website views per year

At BMC, research is always in progress.

Learn more biomedcentral.com/submission 